Dapat diakses pada: http://jkb.ub.ac.id/index.php/jkb/article/view/2533

Jurnal Kedokteran Brawijaya Vol. 30, No. 4, Agustus 2019, pp. 323-330

Article History: Received 11 Februari 2019, Accepted 26 Mei 2019

Artikel Penelitian

\title{
Pengaruh Pembelajaran dan Penilaian Keterampilan Klinis di Kepaniteraan Umum terhadap Tingkat Kesiapan Mahasiswa Kedokteran Melakukan Keterampilan Klinis di Tahap Profesi
}

\section{Effect of Clinical Skills Learning and Assessment on the Readiness of Medical Student to Perform Clinical Skill in Profession Stage}

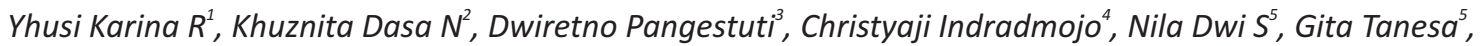 \\ Salis Zainah $S^{5}$ \\ ${ }^{1}$ Departemen IImu Faal Fakultas Kedokteran Universitas Brawijaya Malang \\ ${ }^{2}$ Departemen IImu Anatomi Fakultas Kedokteran Universitas Brawijaya Malang \\ ${ }^{3}$ Departemen Rehabilitasi Medik Fakultas Kedokteran Universitas Brawijaya Malang \\ ${ }^{4}$ Fakultas Kedokteran Universitas Islam Malik Maulana Ibrahim Malang \\ ${ }^{5}$ Program Studi Sarjana Kedokteran Fakultas Kedokteran Universitas Brawijaya Malang
}

\begin{abstract}
ABSTRAK
Pembelajaran keterampilan klinis selama tahap akademik dan Objective Structural Clinical Examination (OSCE) dengan metode simulasi berbeda dengan situasi yang nyata terhadap pasien pada tahap Profesi. Penelitian ini bertujuan membuktikan pengaruh pembelajaran dan penilaian keterampilan klinis yang dinilai menggunakan perubahan persepsi kesiapan melakukan keterampilan klinis sebelum dan sesudah menjalani kepaniteraan umum dibandingkan ketika menjalani tahap Profesi. Studi Kohort dilakukan dengan menggunakan kuisioner persepsi tingkat kesiapan mahasiswa melakukan keterampilan klinis yang diberikan sebelum, setelah Panum dan saat awal Profesi. Jumlah responden dalam penelitian ini 126 mahasiswa Program Studi Profesi Dokter Universitas Brawijaya tahun ke-4. Hasil menunjukkan peningkatan kesiapan mahasiswa dalam melakukan keterampilan klinis sebelum dengan sesudah kepaniteraan umum/Panum $(35,45,5$ dan $39,26,0 ; p<0,05)$, namun tidak terjadi peningkatan ataupun penurunan kesiapan sesudah Panum dengan kesiapan di awal tahap Profesi $(39,26,0$ dan 39,26,1; $>>0,05)$. Tidak ada hubungan signifikan nilai OSCE Panum dengan kesiapan mahasiswa dalam melakukan keterampilan klinis di tahap Profesi melalui uji korelasi SpearmanRho $(p>0,05)$. Proses pembelajaran keterampilan klinis di kepaniteraan umum berpengaruh positif meningkatkan kesiapan melakukan keterampilan klinis sebelum menjalani tahap Profesi hingga awal tahap Profesi. Tidak terdapat hubungan yang bermakna antara nilai OSCE Panum dengan kesiapan mahasiswa dalam melakukan keterampilan klinis di awal tahap Profesi. Perlu di lakukan modifikasi model pembelajaran keterampilan klinis untuk meningkatkan kesiapan mahasiswa dalam melakukan keterampilan klinis pada tahap Profesi.
\end{abstract}

Kata Kunci: Kepaniteraan umum, kesiapan, keterampilan klinis, mahasiswa kedokteran, tahap profesi

\section{ABSTRAK}

Clinical skills learning situation during the academic stage along with the Objective Structural Clinical Examination (OSCE) using simulation-based education method is different from the real situation of patients in the profession stage. This study aimed to prove the effect of learning and assessment of clinical skills that were assessed using changes in perception of readiness to perform clinical skills before and after undergoing general clerkship stage compared to undergoing the professional stage. This study used a cohort study using a perception questionnaire on the level of readiness of students before and after the general clerkship period and at the beginning of the profession. The number of respondents in this study was 126 students of the 4th year of the Study Program of Medicine, Faculty of Medicine, Universitas Brawijaya. Results showed an increase in students' readiness in conducting clinical skills before and after general clerkship (35.45.5 and 39.26.0; $p<0.05)$, but there was no increase or decrease in readiness after general clerkship with the readiness at the beginning of the Professional stage (39.26.0 and 39.26.1; $p>0.05)$. There was no relationship between the general clerkship OSCE grade and the readiness of students to perform clinical skills at early Profession stage using Spearman-Rho correlation test $p>0.05$. The process of learning clinical skills in general in the public registrar has a positive effect in increasing the readiness to carry out clinical skills before undergoing the Professional stage, such readiness is maintained at the beginning of the Professional stage. In addition, there is no significant relationship between the OSCE general clerkship grade and the readiness perception of students to perform clinical skill in the early Profession stage. So, it is necessary to modify the clinical skills learning model to improve the readiness of students to perform the clinical skill at early Profession stage.

Keywords: clinical skill, general clerkship program, medical student, profession stage, readiness

Korespondensi: Yhusi Karina R. Departemen Ilmu Faal Fakultas Kedokteran Universitas Brawijaya Malang, Jl. Veteran, Malang Tel. 08563531837Email:yhusi@yahoo.com

DOI: http://dx.doi.org/10.21776/ub.jkb.2019.030.04.17 


\section{PENDAHULUAN}

Penguasaan keterampilan klinis merupakan elemen yang penting dari mutu professional lulusan pendidikan tinggi kesehatan kedokteran $(1,2)$. Pada mulanya keterampilan klinis dasar diajarkan secara langsung melalui praktek melakukan keterampilan klinis secara langsung pada pasien di bawah bimbingan pembimbing klinik pada saat mahasiswa memasuki kepaniteraan klinik atau tahap pendidikan Profesi di rumah sakit pendidikan. Namun seiring dengan tersusunnya Standar Kompetensi Dokter Indonesia (SKDI), meningkatnya tuntutan pasien atas profesionalisme dan kebutuhan mahasiswa, dibuktikan bahwa kepaniteraan klinik saja tidak cukup untuk memberikan pembekalan keterampilan klinis dasar yang komprehensif. Oleh karena itu, diperkenalkan sebuah modifikasi sistem pengajaran yang disebut laboratorium keterampilan klinis atau skill lab (3). Skill lab merupakan wahana bagi mahasiswa untuk belajar keterampilan klinis dasar dengan pengaturan dokter-pasien namun dilakukan dalam suasana latihan (4).

Di Fakultas Kedokteran Universitas Brawijaya, mahasiswa kedokteran wajib menjalani pendidikan akademik selama 3,5 tahun sebagai bekal untuk menempuh pendidikan Profesi selama 96 minggu. Selama menempuh Pendidikan akademik mahasiswa dibekali teori tentang sebagian besar jenis penyakit, termasuk teori dan praktik keterampilan klinis dengan bantuan manekin atau pasien simulasi yang kemudian akan diuji menggunakan OSCE (Objective Structured Clinical Examination) dengan harapan ketika menjalani tahap Profesi mahasiswa telah siap menghadapi pasien sesungguhnya (5). Selain pembelajaran reguler tersebut, juga diselenggarakan suatu program kepaniteraan umum (Panum) selama 1 bulan, setelah menyelesaikan tahap akademik untuk menjembatani jurang pemisah antara kuliah yang diberikan kepada mahasiswa di ruang kelas dengan situasi klinik kelak saat menangani pasien. Metode pembelajaran pada program kepaniteraan umum ini juga masih menggunakan model pembelajaran yang sama pada tahap akademik yang disebut SBME (Simulation Based Medical Education) dan juga diuji menggunakan OSCE.

Simulation Based Medical Education sebagai bentuk simulasi klinik menerapkan prosedur yaitu situasi atau keadaan pembelajaran dibuat mirip dengan situasi klinik yang nyata, dibantu dengan menggunakan manekin maupun pasien simulasi (6). Melalui simulasi klinik ini, mahasiswa kedokteran akan mendapatkan kesempatan untuk berlatih sebelum nantinya berhadapan dengan pasien langsung. Simulasi dengan menggunakan manekin akan membantu mahasiswa belajar prosedur keterampilan klinis seperti latihan BLS (Basic Life Support) atau resusitasi, pemasangan kateter, rawat jahit luka, dan lain sebagainya. Pada penggunaan pasien simulasi atau pasien yang sudah terstandarisasi, mahasiswa dapat berlatih dan meningkatkan kemampuan klinik mereka melalui feedback yang didapatkan dari pasien simulasi (6). Pasien simulasi dapat membantu mahasiswa mendapatkan gambaran emosi atau reaksi pasien saat berhadapan dengan dokter (misalkan saat melakukan keterampilan anamnesis) serta berlatih berkomunikasi antara dokter dan pasien.

Selain itu, di dalam SBME, mahasiswa tidak hanya belajar keterampilan klinis prosedural. Mahasiswa kedokteran tersebut juga akan mendapatkan pembelajaran softskill secara tidak langsung, seperti melatih komunikasi antar tim, kepemimpinan, pengambilan keputusan, mengendalikan stres, dan lain sebagainya (7). Namun demikian, dengan berbagai kelebihan, simulasi klinik ini tetap tidak bisa disamakan dengan situasi klinik yang realistis nantinya.

Dalam penelitian lain disebutkan bahwa mahasiswa merasa tidak percaya diri dengan skill yang baru dipelajari saat pembelajaran keterampilan klinis sebelum kelulusan tahap akademik. Hal tersebut karena selama ini mahasiswa hanya melihat prosedurnya tapi tidak melakukannya sendiri saat menjalani pendidikan. Lain halnya, mahasiswa akan lebih merasa percaya diri melakukan pemeriksaan tekanan darah, anamnesis, atau skill lain yang memang sudah didapatkan dan dilatih dalam pembelajaran keterampilan klinis saat menjalani pendidikan semester 1 sampai 7. Selain dari alasan tersebut, tidak semua mahasiswa mendapatkan kesempatan berlatih yang sama saat menjalani pembelajaran simulasi. Alasan yang potensial adalah terkait waktu atau jam berlatih, keterbatasan pengajar, dan banyaknya peserta didik (7).

Penelitian pada mahasiswa keperawatan juga merasa bahwa mereka belum sepenuhnya siap dan khawatir serta panik untuk menjalankan tugas mereka ketika berhadapan dengan pasien secara langsung. Hal ini dikarenakan adanya perbedaan antara melakukan keterampilan klinis pada manekin dibandingkan dengan pasien sesungguhnya. Seperti penelitian yang dilakukan oleh Widyandana et al. (8), yang menyatakan bahwa mahasiswa merasakan kesulitan ketika melakukan keterampilan klinis pada pasien sesungguhnya dibandingkan dengan manekin, hal ini dikarenakan kulit pada pasien sesungguhnya lebih elastis dibandingkan dengan manekin. Mahasiswa juga mengungkapkan bahwa ketika mereka melakukan keterampilan klinis terhadap pasien sesungguhnya akan muncul rasa khawatir, karena pasien akan merespon terhadap tindakan yang dilakukan seperti menjerit dan menangis, hal ini berbeda dengan manekin yang hanya diam saja (8).

Setelah melakukan SBME di dalam Panum, mahasiswa kedokteran akan melaksanakan OSCE di akhir pembelajaran. Salah satu kelebihan OSCE adalah dapat menilai kemampuan atau keterampilan klinis yang tidak dapat dinilai melalui ujian tertulis seperti soal pilihan ganda atau essay (9). Mahasiswa akan dihadapkan dengan berbagai kasus baik yang harus diselesaikan dengan menggunakan manekin atau pasien simulasi. Dalam pelaksanaannya, sebagian besar mahasiswa merasakan stres dan gugup saat menjalani OSCE. Perasaan stres dan gugup tersebut dapat disebabkan oleh banyak faktor, seperti kurang familiar dengan prosedur pemeriksaan yang harus dilakukan, adanya penguji, atau pertanyaan yang tidak standard (9). Hal-hal tersebut tentunya akan berpengaruh terhadap nilai OSCE.

Sistem OSCE hanya menggambarkan situasi "bagaimana cara melakukan", bukan melakukan yang sesungguhnya terhadap pasien langsung (6). Hal ini dikarenakan mahasiswa tidak siap dalam menghadapi pasien sesungguhnya. Pada pembelajaran keterampilan klinis di tahap akademik dan kepaniteraan umum, mahasiswa kedokteran tidak dipaparkan secara langsung pada pasien sesungguhnya. Hal ini sesuai dengan penelitian kohort sebelum dan sesaat mahasiswa keperawatan Monash 
University Australia di tempatkan pada praktik klinik yang sesungguhnya di rumah sakit. Dalam penelitian tersebut didapatkan bahwa mahasiswa keperawatan mengalami penurunan kesiapan saat memasuki praktik klinik yang sesungguhnya. Mahasiswa keperawatan yang baru menjalani praktik klinik di rumah sakit merasa tidak kompeten dan tidak memiliki kepercayaan diri. Hal ini didukung dengan pernyataan bahwa mahasiswa keperawatan merasa takut melakukan kesalahan dan takut untuk melukai pasien (10).

Berdasarkan fakta di atas, maka sebenarnya perlu dilakukan evaluasi terkait proses pembelajaran keterampilan klinis khususnya kepaniteraan umum yang dinilai melalui penilaian persepsi tingkat kesiapan melakukan keterampilan klinis sesuai tujuan pembelajaran kepaniteraan umum. Penilaian tingkat kesiapan mahasiswa tersebut dilakukan sebelum, setelah kepaniteraan umum dan saat awal memasuki tahap Profesi ketika menghadapi pasien sesungguhnya. Selain itu untuk menilai kesesuaian antara penilaian keterampilan klinis selama ini menggunakan OSCE dengan tingkat kesiapan setelah Panum dan awal Profesi, maka perlu di teliti ada tidaknya hubungan antara nilai OSCE setelah Panum dengan tingkat kesiapan setelah Panum dan saat awal memasuki tahap Profesi. Perbedaan situasi simulasi selama di Panum dan ketika menghadapi pasien sesungguhnya saat di Profesi kemungkinan akan mempengaruhi tingkat kesiapan mahasiswa dan hubungan antara nilai OSCE dan tingkat kesiapan tersebut.

\section{METODE}

Penelitian ini menggunakan desain penelitian kohort. Penyebaran kuesioner terdiri dari tiga tahap, tahap pertama kuesioner dibagikan sebelum mahasiswa memasuki kepaniteraan umum, tahap kedua kuesioner dibagikan setelah mahasiswa selesai mengikuti kepaniteraan umum, dan tahap ketiga kuesioner dibagikan saat mahasiswa telah memasuki tahap Profesi/kepaniteraan klinik di rumah sakit pendidikan.

\section{Populasi dan Sampel}

Populasi penelitian ini adalah mahasiswa Program Studi Sarjana Kedokteran (PS Sked) Fakultas Kedokteran Universitas Brawijaya (FKUB) angkatan tahun ke-4 yang menjalani Kepaniteraan Umum (Panum) sejumlah 215 mahasiswa. Sampel penelitian ini adalah mahasiswa angkatan tahun ke-4 yang berada dalam keadaan mampu secara fisik dan mental untuk mengisi kuesioner penelitian dan bersedia mengikuti penelitian. Kelompok mahasiswa yang tercakup dalam penelitian ini hanyalah gelombang pertama dan kedua Panum sejumlah 193 mahasiswa dari tiga gelombang Panum. Metode pemilihan sampel menggunakan purposive sampling yaitu peneliti memilih responden berdasarkan pada pertimbangan subjektif dan praktis bahwa setiap responden tersebut dapat memberikan informasi yang memadai untuk menjawab pertanyaan peneliti.

\section{Variabel Penelitian}

Tingkat kesiapan melakukan keterampilan klinis sebelum kepaniteraan umum, tingkat kesiapan melakukan keterampilan klinis setelah kepaniteraan umum, tingkat kesiapan melakukan keterampilan klinis saat tahap awal Profesi (1-3 bulan pertama) dan nilai OSCE Panum.

\section{Lokasi dan Waktu Penelitian}

Penelitian ini dilakukan di Fakultas Kedokteran Universitas Brawijaya pada bulan Februari 2018 sampai dengan bulan Agustus 2018.

\section{Instrumen Penelitian}

Kuisioner tingkat kesiapan untuk menilai persepsi mahasiswa terhadap tingkat kesiapan melakukan keterampilan klinis secara umum dikembangkan mandiri berdasarkan beberapa penelitian sebelumnya $(7,11,12)$. Kuisioner yang tersusun dilakukan uji validitas dan reliabilitas terhadap masing-masing item pertanyaan sebelum digunakan untuk penelitian untuk mengetahui kelayakan setiap masing-masing pertanyaan. Kuisioner tersebut terdiri dari 15 pertanyaan berupa 11 pertanyan positif dan 4 pertanyaan negatif seputar persepsi terhadap efek positif pembelajaran terhadap kemampuan diri, keyakinan dan kepercayaan diri dalam menguasai, menjelaskan kembali dan melakukan keterampilan klinis secara umum tersebut. Jawaban di klasifikasikan dengan skala likert antara 1 sampai dengan 5 dari sangat tidak setuju hingga sangat setuju. Setiap pertanyaan positif terdapat lima pilihan jawaban dengan skor Sangat Setuju $(S S)=4$; Setuju $(S)=3$, Ragu-Ragu $(R R)=2$, Tidak Setuju $(T S)=1$; Sangat Tidak Setuju (STS) $=0$. Pada setiap pertanyaan negatif diberikan penilaian sebaliknya secara berurutan. Hasil penilaian dari jawaban pada data kuesioner kesiapan didapatkan dengan menjumlah seluruh skor yang didapat, lalu diklasifikasikan menjadi beberapa kategori sebagai Tidak Siap=0-15; Kurang Siap $=16-30$; Siap=31-45; Sangat Siap=46-60. Nilai maksimal penilaian kuisioner adalah 60. Daftar Nilai OSCE Panum yang diperoleh dari Bagian Akademik Program Studi Pendidikan Dokter.

\section{Teknik Analisis Data}

Dilakukan pemeriksaan kelengkapan dan kesusaian data yang terkumpul. Data selanjutnya dimasukkan ke dalam komputer dalam bentuk file excel. Analisis data meliputi analisis deskriptif dan uji hipotesis. Pada analisis deskriptif data berskala kategorial seperti tingkat kesiapan dalam bentuk distribusi frekuensi.

Uji hipotesis yang dilakukan menggunakan uji Friedman dan uji Wilcoxon untuk menentukan perbedaan antara variabel tingkat kesiapan sebelum dan sesudah Panum, sesudah Panum dengan awal Profesi. Selanjutnya, dilakukan uji Korelasi Spearman untuk menentukan keterkaitan antara tingkat kesiapan sesudah Panum dan awal Profesi dengan nilai OSCE. Besarnya pengaruh variabel bebas terhadap variabel terikat dinyatakan dengan interval kepercayaan (nilai p) dianggap bermakna apabila $\mathrm{p}<0,05$. Analisis data dilakukan menggunakan SPSS (Statistical Product of Service Solution) versi 24.

\section{HASIL}

Tingkat pengembalian kuesioner (response rate) sebesar $68 \%$, dihitung dari persentase jumlah kuesioner yang kembali tanpa melihat kelayakan (131 kuesioner) dibagi dengan total kuesioner yang disebar yaitu sebanyak 193 kuesioner. Kuesioner yang dapat digunakan (usable response rate) sebesar $65 \%$, dihitung dari jumlah kuesioner yang memenuhi kriteria inklusi (126 kuesioner). Oleh karena penelitian ini merupakan suatu rangkaian penelitian kohort, hal ini dapat menjadi salah satu penyebab yang membuat sampel tidak bersedia menjadi 
responden, serta terdapat sampel yang tidak melengkapi kuesioner yang telah dibagikan pada setiap tahapnya/tidak dapat mengikuti sampai selesai (drop out).

Hasil analisis pertanyaan kuesioner (Supplementary material Tabel 1) menunjukkan bahwa sebagian besar mahasiswa memliki peningkatan persepsi positif terhadap hasil pembelajaran yang meningkatkan kepercayaan dan kemampuannya untuk melakukan keterampilan klinis dari sebelum Panum ke setelah Panum (peningkatan persentase mahasiswa yang "setuju" terhadap pernyataan) hingga saat awal tahap Profesi (peningkatan persentase mahasiswa yang "sangat setuju" terhadap pernyataan). Pada persepsi tingkat kesiapan mengaplikasikan hasil pembelajaran, ketika sebelum dan setelah Panum, persentase mahasiswa sebagian besar pada "ragu-ragu" dan "setuju". Kemudian meningkat menjadi "setuju" dan "sangat setuju" pada awal tahap Profesi. Pada tingkat kepercayaan diri dalam mengaplikasikan hasil pembelajaran, juga terjadi peningkatan pada aspek kepercayaan diri, kenyamanan, keyakinan dalam melakukan keterampilan klinis sesuai dengan prosedur, kemampuan penguasaan dan menjelaskan ke orang lain prosedur keterampilan klinis yang dilakukan. Tingkat kekhawatiran merasa tidak bisa/mengalami kesulitan/ kegugupan/kemungkinan melakukan kesalahan melakukan keterampilan klinis mengalami penurunan meskipun jawaban masih di dominasi dengan pernyataan "ragu-ragu".

\section{Statistik Gambaran Karakteristik Responden}

Beberapa karakteristik demografi responden yang diamati dalam penelitian ini adalah adalah jenis kelamin mahasiswa, usia mahasiswa, jalur masuk ketika memasuki perguruan tinggi, IPK mahasiswa, dan nilai OSCE Panum. Semua karakteristik tersebut akan dipaparkan secara deskriptif dalam bentuk tabulasi seperti pada tabel 1 berikut. Pada Tabel 1 menunjukkan bahwa responden mayoritas berjenis kelamin perempuan. Usia mahasiswa yang paling muda adalah 19 tahun, paling tua adalah 25 tahun dan terbanyak berusia 22 tahun. Berdasarkan jalur masuk saat memasuki perguruan tinggi paling banyak adalah jalur mandiri dan SBMPTN. Adapun nilai IPK yang paling banyak termasuk dalam kategori sangat memuaskan dan nilai OSCE Panum yang paling banyak diperoleh adalah nilai A.

Pengaruh Pembelajaran Keterampilan Klinis terhadap Tingkat Kesiapan Mahasiswa Kedokteran dalam Melakukan Keterampilan klinis sebelum, setelah Panum dan awal Profesi

Untuk mengetahui ada atau tidaknya perbedaan tingkat kesiapan mahasiswa dalam melakukan keterampilan klinis sebelum, sesudah menjalani kepaniteraan umum dan saat awal Profesi dilakukan uji Wilcoxon. Terdapat peningkatan kesiapan mahasiswa dalam melakukan keterampilan klinis sebelum dengan sesudah kepaniteraan umum/Panum $(35,45,5$ dan $39,26,0 ; p<0,05)$, namun tidak terdapat perbedaan tingkat kesiapan sesudah Panum dengan

Tabel 1. Persentase karakteristik responden dan tingkat kesiapan

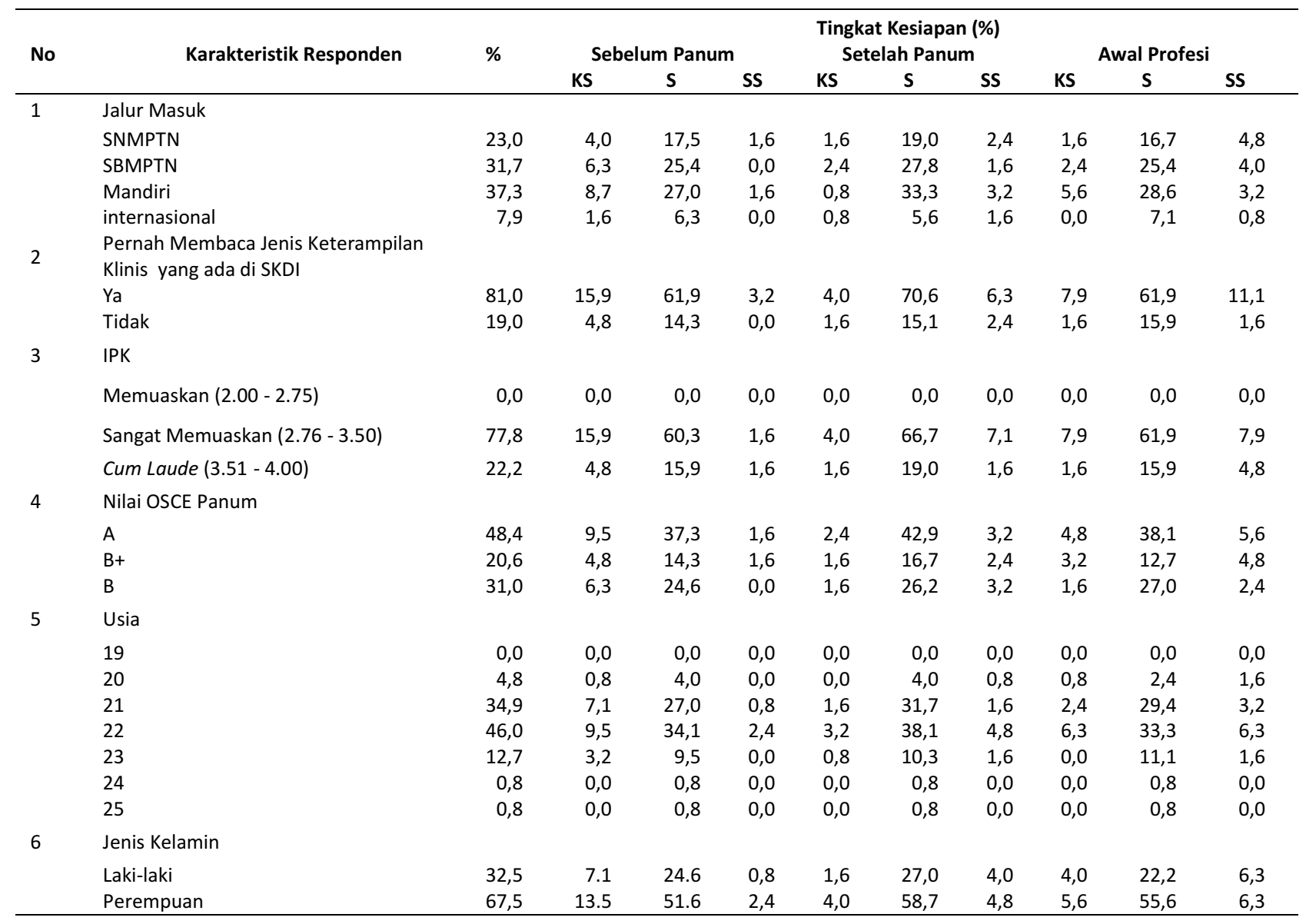

Keterangan : KS:Kurang Siap; S:Siap; SS:Sangat Siap; Panum: Kepaniteraan Umum 
kesiapan di awal tahap Profesi (39,26,0 dan 39,26,1; $\mathrm{p}>0,05)$.

Tabel 2. Skor tingkat kesiapan sebelum, setelah Panum dan awal Profesi

\begin{tabular}{lccc}
\hline Skor Kesiapan & $\begin{array}{c}\text { Sebelum Panum } \\
\mathbf{n}=\mathbf{1 2 6}\end{array}$ & $\begin{array}{c}\text { Setelah Panum } \\
\mathbf{n = 1 2 6}\end{array}$ & $\begin{array}{c}\text { Awal Profesi } \\
\mathbf{n = 1 2 6}\end{array}$ \\
\hline Mean \pm SD & $35,4 \pm 5,8$ & $39,2 \pm 6,1$ & $35,2 \pm 6,5$ \\
Median (range) & $35,0(20-50)$ & $39,0(20-60)^{*}$ & $39,0(23-60)$ \\
\hline
\end{tabular}

${ }^{*} \mathrm{p}<0,05$ uji Wilcoxon dibandingkan dengan nilai sebelum Panum

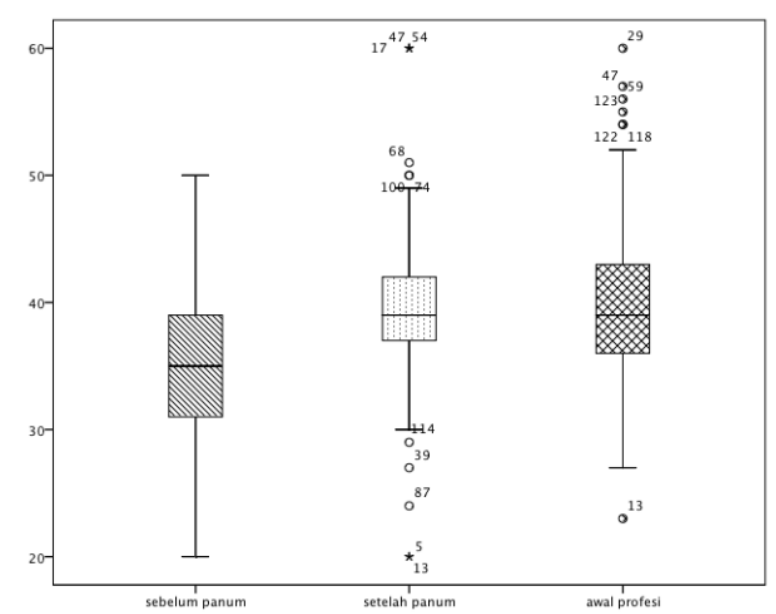

Gambar 1. Box plot perbandingan median skor tingkat kesiapan sebelum Panum dibandingan dengan tingkat kesiapan setelah Panum dan awal Profesi

Hubungan Nilai OSCE Panum dengan Tingkat Kesiapan Mahasiswa dalam Melakukan Keterampilan Setelah Panum dan Awal Profesi

Untuk mengetahui hubungan antara nilai OSCE Panum dengan tingkat kesiapan mahasiswa dalam melakukan keterampilan klinis setelah Panum dan awal Profesi dilakukan uji korelasi Spearman. Dari hasil analisis pada Tabel 3, tidak terdapat hubungan yang bermakna antara nilai OSCE Panum dengan kesiapan mahasiswa melakukan keterampilan klinis $(p>0,05)$.

Tabel 3. Hubungan antara nilai OSCE Panum terhadap tingkat kesiapan setelah Panum dan awal Profesi

\begin{tabular}{llrr}
\hline & & Setelah Panum & Awal Profesi \\
\hline \multirow{2}{*}{ Nilai OSCE } & Spearman & $-0,071$ & $-0,001$ \\
& Correlation & 0,429 & 0,995 \\
& $\mathrm{p}$ & 126 & 126 \\
\hline
\end{tabular}

\section{DISKUSI}

Pembelajaran keterampilan klinis yang diajarkan di kepaniteraan umum dengan menggunakan model SBME terbukti dapat meningkatkan skor tingkat kesiapan mahasiswa dalam melakukan keterampilan klinis. Hal ini sesuai dengan sebuah studi yang dilakukan oleh Peyre et al. (13), pada mahasiswa kedokteran tahun ke empat yang akan memasuki rotasi klinik Departemen Bedah di University of Southern California Keck School of Medicine mengenai tingkat kepercayaan diri dan kesiapan dalam melakukan 21 keterampilan bedah sebelum dan sesudah mahasiswa tersebut mengikuti program elektif keterampilan bedah selama 3 minggu. Program elektif yang dimaksud adalah suatu blok pilihan dalam kurikulum kedokteran yang diperuntukkan bagi mahasiswa untuk melatih keterampilan klinis mereka sesuai dengan minat mahasiswa tersebut. Dalam penelitian tersebut diperoleh data bahwa mahasiswa kedokteran tahun ke empat sebelum mengikuti elektif memiliki tingkat kepercayaan diri dan kesiapan yang rendah (71\% responden). Namun, setelah mengikuti elektif tersebut tingkat kepercayaan diri dan kesiapan mahasiswa dalam melakukan keterampilan klinis menjadi meningkat (95\% responden). Dalam penelitian tersebut dikatakan bahwa mahasiswa yang memiliki pengalaman melakukan keterampilan klinis sebelumnya memiliki tingkat percaya diri dan kesiapan yang lebih tinggi dibandingkan dengan mahasiswa yang tidak memiliki pengalaman sebelumnya (13). Berdasarkan penelitian tersebut, pelatihan keterampilan klinis yang diberikan sejak awal kurikulum di tahap preklinik dapat meningkatkan kepercayaan diri untuk melakukan keterampilan klinis.

Program elektif yang diselenggarakan oleh departemen bedah University of Southern California tersebut pada dasarnya memiliki konsep yang sama dengan program kepaniteraan umum (Panum) yang diselenggarakan oleh FK UB selama kurang lebih 2 bulan. Hal ini dikarenakan kedua program tersebut mempunyai tujuan yang sama yaitu untuk mempersiapkan mahasiswa kedokteran dalam melakukan keterampilan klinis sebelum memasuki rotasi klinik di rumah sakit. Hal ini juga senada dengan penelitian yang dilakukan oleh Connor et al. (14), pada mahasiswa kedokteran tahun kedua yang mengikuti elektif. Pada penelitian tersebut, terdapat 2 kelompok mahasiswa yang akan disurvei. Kelompok pertama terdiri dari 20 mahasiswa kedokteran tahun kedua yang telah mengikuti elektif, sedangkan kelompok kedua terdiri dari 22 mahasiswa kedokteran tahun kedua yang termasuk dalam daftar tunggu elektif (masih belum mendapatkan elektif) dikarenakan keterbatasan waktu. Pada penelitian tersebut didapatkan bahwa mahasiswa kedokteran yang mengikuti elektif memiliki kesiapan yang lebih tinggi dalam melakukan pemeriksaan fisik, penilaian dan rencana penanganan masalah kesehatan pasien dibandingkan dengan mahasiswa yang belum pernah atau yang tidak mengikuti elektif sama sekali (14).

Pada penelitian ini tidak terdapat perbedaan tingkat kesiapan mahasiswa melakukan keterampilan klinis sebelum mengikuti Panum dan saat awal Profesi. Hal ini dapat terjadi karena keterampilan klinis yang diterima selama Panum masih cukup di pertahankan sampai tahap awal Profesi. Pernyataan ini sesuai dengan penelitian kohort yang dilakukan oleh Whipple et al., (15), pada mahasiswa kedokteran tahun ketiga University of Washington, yang menyatakan bahwa pemberian training (pelatihan) pada mahasiswa sebelum memasuki tahap Profesi secara signifikan dapat meningkatkan performa dan rasa nyaman bagi mahasiswa untuk melakukan keterampilan klinis tersebut (15). Selain itu, penelitian lain menyebutkan semakin lama periode dan banyak frekuensi pelatihan keterampilan klinis yang didapatkan, maka akan 
semakin meningkat keyakinan dan kesiapannya (10).

Untuk dapat meningkatkan kesiapan mahasiswa pada tahap awal Profesi, dapat dilakukan perubahan model pembelajaran dengan menghadapkan pada situasi klinik secara langsung. Sesuai dengan penelitian yang dilakukan oleh Diemers et al. (16), menyatakan bahwa pembelajaran yang melibatkan kontak langsung dengan pasien akan meningkatkan motivasi belajar mahasiswa, hal ini dikarenakan adanya rasa tanggung jawab dan rasa takut akan gagal ketika melakukan suatu tindakan pada pasien sesungguhnya. Oleh karena itu, mereka akan berusaha untuk belajar dengan baik sebelum berhadapan dengan pasien tersebut. Hal ini tentu saja akan berbeda ketika mahasiswa dihadapkan dengan manekin atau pasien simulasi lainnya. Model pembelajaran ini juga dapat meningkatkan retensi memori mahasiswa, ketika dihadapkan dengan pasien sesungguhnya mahasiswa akan lebih mengingat tentang suatu penyakit dibandingkan dengan hanya membaca pada textbook(16).

Disisi lain, berinteraksi dengan pasien sesungguhnya dapat memberikan pengetahuan baru bagi mahasiswa dan sekaligus dapat memanggil kembali memori pengetahuan dasar yang telah mereka dapatkan sebelumnya, dengan begitu mahasiswa akan dapat mengintegrasikan antara teori yang didapatkan dengan praktik yang akan dilakukan. Dan, yang paling penting adalah pembelajaran dengan melibatkan kontak langsung pasien dapat membantu mereka terbiasa dalam menangani setiap kasus pada pasien tersebut serta dapat membentuk karakter professional masa depan mereka sebagai dokter nantinya. Hal ini tentunya menurut pendapat mereka, tidak dapat dicapai oleh jika hanya mengandalkan manekin atau pasien terstandarisasi lainnya $(3,16)$.

Meskipun nilai OSCE sebagian besar (49\%) responden masuk dalam kategori yang tertinggi atau sangat baik (nilai A), namun ternyata tidak dapat mencerminkan kesiapan mahasiswa melakukan keterampilan klinis saat awal Profesi. Dari 49 responden yang mendapat nilai A, hanya 18 responden yang tergolong "sangat siap", sedangkan sisanya tergolong "siap" pada tingkat kesiapan melakukan keterampilan klinis saat awal Profesi. Hubungan yang tidak bermakna ini dapat disebabkan berbagai faktor. Hal tersebut mungkin dikarenakan tidak semua keterampilan diujikan dalam OSCE Panum, sedangkan banyak keterampilan yang harus dikuasai mahasiswa saat melakukan keterampilan klinis pada tahap Profesi, sehingga nilai OSCE Panum yang bagus tidak menggambarkan bahwa mahasiswa sangat siap melakukan keterampilan klinis pada tahap Profesi nantinya.

OSCE Panum selama ini mungkin hanya digunakan sebagai alat evaluasi pembelajaran keterampilan klinis. Padahal seharusnya OSCE Panum tidak hanya menjadi alat evaluasi pembelajaran saja, tetapi juga dapat menjadi sarana belajar mahasiswa. Tidak hanya itu, seharusnya ada transparansi nilai OSCE Panum sehingga mahasiswa mendapatkan feedback dan mengetahui di mana letak kesalahan pembelajaran mereka. Dengan begitu, OSCE dapat menjadi alat evaluasi pembelajaran keterampilan klinis sekaligus sebagai sarana belajar bagi mahasiswa kedokteran sehingga diharapkan mahasiswa kedokteran tersebut menjadi lebih siap (17).

Faktor lain yang menyebabkan tidak adanya hubungan antara nilai OSCE tersebut dengan tingkat kesiapan adalah pada OSCE Panum menggunakan metode simulasi dengan manekin atau pasien terstandarisasi yang berbeda situasinya dengan pasien sesungguhnya saat nanti di tahap Profesi. Dengan demikian, mahasiswa merasa tidak yakin karena OSCE tersebut hanya menggambarkan situasi "bagaimana cara melakukan" tetapi bukan melakukan yang sesungguhnya terhadap pasien real saat di tahap Profesi nantinya (6). Perasaan atau situasi yang berbeda dalam menghadapi pasien simulasi dan pasien real tersebut dapat menyebabkan tidak adanya hubungan tersebut kesiapan mahasiswa dalam melakukan keterampilan klinis pada pasien sesungguhnya (18).

Pada penelitian lain dijelaskan bahwa mahasiswa akan merasa lebih siap apabila mereka mendapatkan sistem pembelajaran pre-clerkships, yaitu pembelajaran dengan sistem rotasi di mana mahasiswa dapat langsung melakukan obervasi secara langsung dengan pasien yang sesungguhnya, sebelum nantinya berada pada tahap Profesi melakukan keterampilan klinis secara langsung pada pasien di bawah supervise (20). Apabila mahasiswa mengikuti pre-clerkships, mahasiswa akan mendapatkan pengalaman klinis yang lebih nyata. Selain itu, preclerkships akan meningkatkan motivasi mahasiswa untuk mengasah keterampilan klinis mereka karena mereka dihadapkan langsung dengan situasi pasien yang sesungguhnya (20). Mahasiswa juga belajar berkolaborasi dengan tim tenaga kesehatan lain, belajar mengenai Profesionalisme saat berhadapan langsung dengan pasien. Melalui pengalaman ini, mahasiswa akan lebih mengerti teori atau pengetahuan tentang keterampilan klinis yang telah dipelajari ketika mereka belajar praktik langsung terhadap pasien sesungguhnya walaupun hanya observasi di bawah supervisi. Semakin lama paparan juga akan makin meningkatkan tingkat keyakinan dan kepercayaan $\operatorname{diri}(10,19)$.

Meskipun demikian, seperti yang telah dijelaskan di atas, karena sistem OSCE Panum menggunakan sistem simulasi menyebabkan nilai OSCE Panum tidak memiliki hubungan yang bermakna dengan kesiapan mahasiswa dan tidak dapat merepresentasikan kesiapan mahasiswa dalam melakukan keterampilan klinis pada tahap Profesi. Penilaian tingkat kesiapan pada studi ini di dapatkan dari penilaian persepsi pribadi terhadap diri sendiri, berbeda dengan penilaian dari orang lain yang lebih kompenten seperti dosen atau pembimbing klinik pada OSCE. Beberapa penelitian sebelumnya menyatakan adanya gap antara penilaian keyakinan dan kepercayaan diri pribadi dengan pendapat orang lain terhadap kompetensi performa sesungguhnya. Patricia et al. (20), bahkan menunjukkan adanya korelasi negatif antara persepsi pribadi atas kompetensinya melakukan keterampilan klinis dibandingkan dengan penilaian obyektif menggunakan OSCE karena ketakutan mengetahui kelemahan dan menyadari jika ternyata mereka tidak dapat mencapai kompetensi yang diharapkan. Meskipun penilaian pribadi tidak dapat merefleksikan kompetensi sesungguhnya, kemampuan menilai kompetensi diri sendiri untuk seorang dokter sangat penting untuk mengetahui kemampuan dan keterbatasan dalam keputusan melakukan tindakan pada pasien secara mandiri atau merujuk ke kolega yang lebih sesuai. Chen et al. (21), menyatakan bahwa mahasiswa kedokteran yang tingkat keyakinan dan kepercayaan dirinya dalam melakukan keterampilan klinis rendah akan sulit menyesuaikan dengan kebutuhan pasien dan masyarakat $(20,21)$. 
Penilaian terhadap kemampuan diri sendiri sering disebut self efficancy dipengaruhi beberapa faktor antara lain pengalaman keberhasilan/kegagalan sebelumnya, pesan yang di sampaikan orang lain dan keberhasilan/kegagalan orang lain. Mahasiswa akan merasa lebih yakin berhasil ketika melakukan tugas yang sama yang pernah berhasil sebelumnya. Pesan berupa umpan balik dari orang lain membantu evaluasi diri untuk meningkatkan keyakinan pada tugas selanjutnya. Pengalaman orang lain yang berhasil juga menjadi cerminan untuk refleksi meningkatkan keyakinan atas kemamuannya melakukan tugas yang sama (22). Penilaian orang lain dalam hal ini penguji OSCE dipengaruhi oleh pengalaman menguji dan pengalaman klinis sesuai bidang yang diuji sebelumnya $(23,24)$.

Berdasarkan hasil dan pembahasan di atas menunjukkan nilai OSCE Panum tidak berpengaruh dalam menentukan tingkat kesiapan mahasiswa dalam melakukan keterampilan klinis saat awal Profesi. Pencapaian kompentensi keterampilan klinis pada Tahap Akademik di FKUB dibagi dalam batasan knows (tahu atau pengetahuan dasar), knows how (tahu bagaimana melakukan), show how (menunjukan bagaimana melakukan) sesuai dengan diagram pencapaian kompetensi menurut Miller yang tercantum dalam SKDI (Standar Kompetensi Dokter Indonesia) (1,5), sehingga metode penilaian yang paling sesuai adalah OSCE. Meskipun demikian dapat dilakukan modifikasi penilaian yang dapat menggambarkan tingkat kesiapan mahasiswa salah satunya berupa Formative OSCE dalam bentuk Group OSCE (GOSCE) yang disertai dengan pemberian umpan balik pada mahasiswa oleh peer dan pembimbing klinis. Penelitian yang dilakukan oleh Universitas Sharjah menunjukkan bahwa pemberian GOSCE mendukung peningkatan performa mahasiswa dan memberikan lingkungan pembelajaran yang lebih menyenangkan karena adanya refleksi pembelajaran dan dukungan berupa umpan balik dari peer dan tutor (25). Modifikasi metode ini membutuhkan perubahan kurikulum untuk penambahan waktu Panum yang akan membutuhkan waktu lebih dari 1 bulan untuk sejumlah kompetensi tingkat 4 pilihan dari total 423 keterampilan klinis yang wajib dikuasai lulusan dokter yang tercantum dalam SKDI (1). Perlu juga dipertimbangkan kesiapan jumlah tutor sesuai kompetensi keterampilan klinis pada Panum tersebut.

Penelitian ini memiliki keterbatasan diantaranya hanya menggunakan kuesioner yang dibagikan kepada responden sehingga kesimpulan yang didapat hanya berdasarkan pada data yang dikumpulkan melalui kuesioner tersebut. Penelitian lebih lanjut dengan metode wawancara pada responden mengenai persepsi kesiapan melakukan keterampilan klinis pada pasien sesungguhnya akan sangat membantu. Penelitian dengan menggunakan metode eksperimen untuk melakukan menggunakan alat dan bahan yang sesuai dengan jenis keterampilan klinis tertentu yang di nilai, akan sangat membantu untuk melihat secara objektif hasil performa mahasiswa dalam

\section{DAFTAR PUSTAKA}

1. Hashim R, Qamar K, Khan MA, and Rehman S. Role of Skill Laboratory Training in Medical EducationStudents\&rsquo; Perspective. Journal of College of Physicians and Surgeons Pakistan. 2016; 26(3): 195198. melakukan keterampilan klinis tersebut. Misalnya pengujian keterampilan klinis jahit luka menggunakan penilaian langsung Mini-CEX (Mini Clinical Evaluasition Exercise Examination) pada saat mahasiswa menjahit luka pasien di bawah bimbingan pembimbing klinik di tahap Profesi atau menggunakan animal model pada tahap awal rotasi klinik Bedah. Jumlah sampel pada penelitian ini dapat disimpulkan masih kurang karena belum memenuhi jumlah sampel minimal. Hal ini dikarenakan pengisian kuesioner yang tidak memenuhi kriteria inklusi serta terdapat sampel yang tidak dapat mengikuti penelitian sampai selesai (drop out). Untuk dapat mengurangi drop out, diharapkan kuisioner sejenis dengan lebih detail masing-masing jenis keterampilan yang dinilai dapat dijadikan prosedur rutin resmi yang wajib diisi mahasiswa sebelum, setelah Panum dan ketika tahap Profesi sebagai evaluasi pendidikan tahap Akademik. Dengan evaluasi tersebut diharapkan dapat menjadi dasar untuk mempertahankan atau meningkatkan kesiapan mahasiswa dalam menunjukkan kemampuan does (dapat melakukan secara mandiri) yaitu melakukan keterampilan klinis pada pasien secara langsung dibawah pengawasan pembimbing klinik saat tahap Profesi.

Berdasarkan hasil penelitian dan pembahasan penelitian mengenai efektivitas pembelajaran keterampilan klinis terhadap kesiapan keterampilan klinis di tahap Profesi, maka dapat disimpulkan bahwa terdapat pengaruh positif pembelajaran keterampilan klinis terhadap tingkat kesiapan mahasiswa kedokteran dalam melakukan keterampilan klinis sebelum dan sesudah menjalani Panum. Namun, tidak terdapat pengaruh pembelajaran keterampilan klinis terhadap tingkat kesiapan mahasiswa kedokteran dalam melakukan keterampilan klinis saat menjalani awal Profesi. Selain itu juga ternyata tidak terdapat hubungan antara nilai OSCE Panum terhadap tingkat kesiapan mahasiswa kedokteran dalam melakukan keterampilan klinis sebelum, sesudah menjalani Panum dan saat awal Profesi.

\section{UCAPAN TERIMAKASIH}

Terima kasih kami sampaikan kepada mahasiswa Program Studi Sarjana Kedokteran yang bersedia mengikuti penelitian ini, dan Hasna Okta Asrofi dan Ivan Wicaksono yang telah membantu tahap awal penelitian, BPPM Fakultas Kedokteran Universitas Brawijaya atas bantuan biayanya melalui DPP/SPP. Terima kasih kami sampaikan kepada Dekan Fakultas Kedokteran, Ketua Jurusan, Ketua Program Studi Sarjana Kedokteran, Tim Panum, Ketua Program Studi Profesi Dokter atas dukungan dan ijinnya dalam melakukan penelitian ini. Terima kasih setinggitingginya kepada DR.dr. Sri Andarini, MKes., dr. Triwahju Astuti, M.Kes, Sp.P(K) serta Dr.dr. Jack Roebiyoso, MSc (OM) PKK yang telah membantu dengan sabar dalam membimbing penelitian dan mahasiswa yang terlibat dalam penelitian ini serta memperlancar terlaksananya penelitian ini.
2. Amin Z. Basics in Medical Education. Second. Singapore: World Scientific Publishing; 2009.

3. Vogel D and Harendza S. Basic Practical Skills Teaching and Learning in Undergraduate Medical Education-A Review on Methodological Evidence. GMS Journal for Medical Education. 2016; 33(4): 1-9. 
4. Direktorat Jenderal Pendidikan Tinggi kementerian Pendidikan dan Kebudayaan. Guideline Penguji OSCE Kedokteran. Jakarta: Direktorat Jenderal Pendidikan Tinggi kementerian Pendidikan dan Kebudayaan; 2010.

5. Fakultas Kedokteran Universitas Brawijaya. Pedoman-PSPD-TA.2017-2018.Pdf. Malang: Fakultas Kedokteran Universitas Brawijaya; 2016.

6. Akaike $\mathrm{M}$, Fukutomi $\mathrm{M}$, Nagamune $\mathrm{M}$, et al. Simulation-Based Medical Education in Clinical Skills Laboratory. The Journal of Medical Investigation. 2012; 59(1-2): 28-35.

7. Gazibara T, Nurković S, Marić G, et al. Ready to Work or Not Quite? Self-Perception of Practical Skills among Medical Students from Serbia Ahead of Graduation. Croatian Medical Journal. 2015; 56(4): 375-382.

8. Widyandana D, Majoor G, and Scherpbier A. Preclinical Students' Experiences in Early Clerkships after Skills Training Partly Offered in Primary Health Care Centers: A Qualitative Study from Indonesia. BioMed Medical Education. 2012; 12(1).

9. Khosravi KA, Salari $\mathrm{S}$, Baharvahdat $\mathrm{H}$, et al. The Assessment of Undergraduate Medical Students' Satisfaction Levels with the Objective Structured Clinical Examination. Iranian Red Crescent Medical Journal. 2014; 16(8): e13088.

10. Porter J, Morphet J, Missen K, and Raymond A. Preparation for High-Acuity Clinical Placement: Confidence Levels of Final-Year Nursing Students. Advances in Medical Education and Practice. 2013; 4:83-89.

11. Bojanić K, Schears GJ, Schroeder DR, Jenkins SM, Warner DO, and Sprung J. Survey of Self-Assessed Preparedness for Clinical Practice in One Croatian Medical School. BioMed Central Research Notes. 2009; 2(1): 152-157.

12. Sudaryono. Pengantar Evaluasi Pendidikan: Berdasarkan Teori Tes Klasik dan Modern. Jakarta: Lentera IImu Cendekia; 2014.

13. Peyre SE, Peyre CG, Sullivan ME, and Towfigh S. A Surgical Skills Elective Can Improve Student Confidence Prior to Internship. Journal of Surgical Research. 2006; 133(1): 11-15.

14. Connor DM, Conlon PJ, O'Brien BC, and Chou CL. Improving Clerkship Preparedness: A Hospital Medicine Elective for Pre-Clerkship Students. Medical Education Online. 2017; 22(1): 1-6.

15. Whipple ME, Barlow CB, Smith S, and Goldstein EA. Early Introduction of Clinical Skills Improves Medical Student Comfort at the Start of Third-Year Clerkships.
Academic Medicine. 2006; 81(10): S40-S43.

16. Diemers AD, Dolmans DH, Verwijnen MG, Heineman $\mathrm{E}$, and Scherpbier AJ. Students' Opinions about the Effects of Preclinical Patient Contacts on Their Learning. Advances in Health Sciences Education: Theory and Practice. 2008; 13(5): 633-647.

17. Lin CW, Clinciu DL, Swartz $\mathrm{MH}$, et al. An Integrative OSCE Methodology for Enhancing the Traditional OSCE Program at Taipei Medical University HospitalA Feasibility Study. BioMed Central Medical Education. 2013; 13: 102-107.

18. Zayyan M. Objective Structured Clinical Examination: The Assessment of Choice. Oman Medical Journal. 2011; 26(4): 219-222.

19. Wijnen-Meijer M, Cate OT, van der Schaaf M, Burgers C, Borleffs J, and Harendza S. Vertically Integrated Medical Education and the Readiness for Practice of Graduates. BioMed Central Medical Education. 2015; 15: 229-238.

20. Katowa-Mukwato $\mathrm{P}$ and Banda S. Self-Perceived Versus Objectively Measured Competence in Performing Clinical Practical Procedures by Final Year Medical Students. International Journal of Medical Education. 2016; 7: 122-129.

21. Chen W, Liao SC, Tsai CH, Huang CC, Lin CC, and Tsai $\mathrm{CH}$. Clinical Skills In Final-Year Medical Students: The Relationship between Self-Reported Confidence and Direct Observation by Faculty or Residents. Annals of the Academy of Medicine Singapore. 2008; 37(1): 3-8.

22. Miswari M. Mengelola Self Efficacy, Perasaan dan Emosi dalam Pembelajaran Melalui Manajemen Diri. Cendekia: Journal of Education and Society. 2017; 15(1): 67-82.

23. Spencer LJ, Marschark M, Machmer E, Durkin A, Borgna G, and Convertino C. Communication Skills of Deaf and Hard-of-Hearing College Students: Objective Measures and Self-Assessment. Journal of Communication Disorders. 2018; 75: 13-24.

24. Karlina I, Judistiani TD, Pratiwi YS, Hilmanto D, Sutedja E, and Suwarsa O. Analisis Kualitas Alat Uji Objective Structure Clinical Examination (OSCE) di Pendidikan Diploma III Kebidanan STIKes Rajawali. Jurnal Pendidikan dan Pelayanan Kebidanan Indonesia (Indonesian Journal of Education and Midwifery Care). 2017; 3(2): 8-14.

25. Sulaiman ND, Shorbagi SI, Abdalla NY, Daghistani MT, Mahmoud IE, and Al-Moslih AM. Group OSCE (GOSCE) as a Formative Clinical Assessment Tool for pre-Clerkship Medical Students at the University of Sharjah. Journal of Taibah University Medical Sciences. 2018; 13(5): 409-414. 